\title{
The Effect of Polymers Combination of Hydroxypropylmethylcellulose and Carboxymethylcellulose Sodium Polymers to The Physical Properties of Patch of Celery (Apium graveolens L.) Ethanolic Extract
}

\author{
Dian Eka Ermawati*, Galuh Kartikasari \\ Departement of Pharmacy, Mathematics and Natural Science Faculty, Universitas Sebelas Maret, \\ Surakarta \\ Corresponding author: Dian Eka Ermawati: Email: dianekae@staff.uns.ac.id \\ Submitted: 03-10-2019 Revised: 10-12-2019 Accepted: 12-02-2020
}

\begin{abstract}
Celery herbs (Apium graveolens L.) contain apigenin compounds (flavonoids) that are effective as antihypertensiv agent. The use of Celery herbs in the form of decoction and oral preparations has disadvantage that is voluminous and can cause gastric irritation. Patches were chosen because it can prevent gastric irritation and reduce the frequency of drug administration because the drug is delivered over the skin with a continuously. This study aimed to evaluate of combination of hydroxypropyl methylcellulose (HPMC) and carboxymethylcellulose sodium (CMC sodium) to the physical properties of patch of celery herbs ethanolic extract. This study was conducted with maceration of celery herbs using ethanol in order to obtaine of polar active constituents and then dispersed in patch made with variations in the concentrations ratio of HPMC and CMC sodium polymers of $3: 1,1: 1$, and 1:3. Patches were tested for physical properties including organoleptic, $\mathrm{pH}$, thickness, weight, folding endurance, and moisture content. Statistical analysis of test data used One Way ANOVA and Paired Samples T Test. The results of statistical analysis showed that the increase concentrations ratio of CMC sodium polymer in the combination of HPMC and CMC sodium polymers could increase the thickness, weight, and moisture content of celery herbs ethanol extract patch. The best patch was formula 2 with the same concentration ratio of HPMC and CMC sodium polymers because it showed the best results with a pH 6,12-6,29, thickness 1,37-1,53 mm, weighting 2,24-2,52 gram, folding endurance more than 300 times, and the moisture content was quite stable.
\end{abstract}

Keywords: celery herbs; patch; HPMC; CMC sodium

\section{INTRODUCTION}

Celery is one of the herbal that used by people to decrease blood presure in hypertension. Celery contains of active compounds such as flavonoids, saponins, tannins 1\%, essential oils $0.033 \%$, flavoglucosides (apiin), apigenin, phytosterols, choline, lipases, phthalids, asparagines, bitter substances, vitamins (A, B and C), and alkaloids (Saputra and Fitria, 2016). One of the main components of flavonoids in celery is apigenin (Al-Snafi, 2014). Apigenin is vasorelaksator that is dilating blood vessels with mechanisms such as calcium antagonists so that it can function as an antihypertensive agent (Palmer, 2007). Ethanol extract of celery that given orally at a dose of $550 \mathrm{mg}$ B.W for 7 days can reduce systolic blood pressure by $6.62 \mathrm{mmHg}$ and diastole by $4.59 \mathrm{mmHg}$ (Dewi et al., 2010).

Celery plants are usually used for treatment by infused into water, but the dosage of the infused water celery is less precise and still contains many components that are not needed for treatment and voluminous, especially amount of drugs taken in a day. The formulation of celery herbal medicines in oral preparations such as liquid, infused and capsules has also begun to be developed, but oral preparations still have side effects such as stomach irritation and require higher doses to get therapeutical effect (Patel et al., 2012). Celery patch is one of drugs delivery system that delivered topically are the choices that are expected to resolve deficiencies in oral preparations and to increase the effectiveness of treatment.

Patch is a dosage form that aims to deliver drugs through the skin membrane into the blood circulation (Valenta and Auner, 2004). Patch preparations have the advantage of being easy to use, reducing the frequency of drug administration, eliminating first-pass metabolism, reducing side effects such as stomach irritation, and increasing patient 
The Effect of Polymers Combination of Hydroxypropylmethylcellulose

Table I. Celery Herb (Apium graveolens L.) Ethanol Extract Patch Formula

\begin{tabular}{llccc}
\hline \multirow{2}{*}{ Ingredients } & \multirow{2}{*}{ Function } & \multicolumn{3}{c}{ Formula (gram) } \\
\cline { 3 - 5 } & Active substances & 0.25 & 0.25 & 0.25 \\
\hline Celery ext & Hydrophylic polimer & 0.30 & 0.20 & 0.10 \\
HPMC & Hydrophylic polimer & 0.10 & 0.20 & 0.30 \\
Na CMC & Plasticizer & 0.40 & 0.40 & 0.40 \\
PEG 400 & Penetration enhancer & 0.30 & 0.30 & 0.30 \\
Propylen glycole & Presetvatives & 0.01 & 0.01 & 0.01 \\
Nypagin & Solvent & 5.00 & 5.00 & 5.00 \\
Etanol 96\% & Solvent & ad 16 & ad 16 & ad 16 \\
Aquadest & & & & \\
\hline
\end{tabular}

compliance (Madhulata and Naga, 2013). Polymers are the main components of the patch matrix and play an important role because the polymers are in charge of controlling drug release from the patch matrix (Sharma et al., 2011). Hydroxylmethylcelulose (HPMC) polymers and Carboxylmethylcellulose (CMC$\mathrm{Na}$ are hydrophilic polymers. Research conducted by Prabhu et al. (2011) that formulated patch preparations with various polymer combinations, it was produced that the formulation with the combination of hydrophilic polymer HPMC and CMC - Na was the best formulation because it provided faster drug release. Formulated patch formula is expected to know the effect of a combination of HPMC polymers and CMC-Na on the physical properties patch of celery herb ethanolic extract and fullfil patch that have good physical properties.

\section{METHODS \\ Material}

Celery leaves herb (Apium graveolens L.) C.V Herbadream Palur, Karanganyar, Central Java, ethanol 96\% technis grade (Brataco), silica GF254, n-butanol (Merck), acetate acid (Merck), aquadest (Agung Jaya), quercetin standard (Sigma), HPMC (Hercules Tianpu), CMC-Na (Changshu Wealthy), nipagin (Agung Jaya), PEG 400 (DOW), propylene glycole (DOW).

\section{Celery Herbs Ethanolic Extraction}

Fresh green celery herbs with dark colour are wet sorted, then washed and drained under sun with a black cloth covered. Dry celery herbs then dry sorted and blended into powder. Amount of 500 gram celery herbal powder was put into maceration jar, macetaed with 2.5 liters of ethanol $96 \%$ until the surface of the powder was completely submerged. Maceration jars are tightly closed, left for 3 days in a light-protected place while occasionally stirring. The maceration results are filtered, then the filtrate is evaporated at temperature of $45-50^{\circ} \mathrm{C}$ with a rotary evaporator, then concentrated with a waterbath until a thick extract is obtained.

\section{Physical Caracteristics of Celery Herbs Ethanolic Extract}

Calculation of extract yield

The extract yield is calculated by means of the weight of the extract obtained (grams) divided by the total weight of the initial simplicia (grams), the results expressed in percent (\%).

\section{Organoleptic examination of extracts}

Organoleptic examination of the extract includes the shape, color, and odor carried out with the senses and aims for a simple and subjective initial introduction.

\section{Water content testing}

Amount of 1.0 gram extract was placed on an empty aluminum pan of the moisture analyzer, then the extract was leveled. The instrument cover is closed and set at a temperature of $105^{\circ} \mathrm{C}$, the moisture analyzer will heat the extract until it shows the value of the sample water content that is read constantly.

\section{Identify flavonoid content}

Flavonoid identification was carried out using Thin Layer Chromatography (TLC) with the stationary phase of the TLC silica gel plate and the mobile phase of $\mathrm{n}$-butanol: acetic acid: water (4:1:5). The standard used is quercetin which is included in the flavonoid total group. The TLC plate was preoven for 3 minutes at $45^{\circ}$ C. Mobile phase n-butanol: acetic acid: water 
(4: $1: 5$ ) is put into the chamber and saturated. The TLC plate that had been dosed with the sample was eluted in the chamber, then the TLC plate was aerated and then spot appearance on the TLC plate under UV light of $254 \mathrm{~nm}$ and 366 nm (Kusnadi and Devi, 2017).

\section{Formulation of Celery Herbs Ethanol Extract Patch}

The patchs of Celery herb (Apium graveolens L.) ethanolic extract were prepared in 3 formulas with varying ratio of HPMC and Na CMC polymer concentrations.

CMC-Na was dissolved in part of aquadest at temperature of $\pm 50^{\circ} \mathrm{C}$. HPMC was dissolved in the remaining aquadest until inflate then put in CMC-Na mucilago. Nipagyn and celery extract were dissolved with $96 \%$ ethanol then put into the mixture, added PEG 400 and propylenglycol, then stirred until homogeneous and put in petri dish molds. The patch is dried at room temperature for 4 days, then packaged and tested. Each formula was made with 3 patches of celery herb ethanol extract.

\section{Physical Properties of Celery Herb Ethanol Extract Patch Test \\ Organoleptic Test \\ Organoleptic tests were performed by observing the shape, color, odor, and surface condition of the patch (Puspitasari et al., 2016).}

pH test

The surface $\mathrm{pH}$ test is carried out by means of a patch put in a container containing $10.0 \mathrm{~mL}$ of CO2-free aquadest at room temperature and allowed to stand for 1 hour, then the surface $\mathrm{pH}$ of the patch is measured with a pH meter (Kumar et al., 2012).

Thickness test

Patch thickness test is done by measuring patch at 5 different points using calipers, then the average is calculated (Madhulata and Naga, 2013).

Weight test

Three patch preparations were weighed one by one with electric scales, then the average weight of each patch was calculated (Parivesh et al., 2010).
Multiplication test

Patch preparation is folded repeatedly in the same place until the patch is broken or folded up to 300 times manually (Jhawat et al., 2013). The number of folds estimates the value of patch resistance to folding (Parivesh et al., 2010).

Humidity test

Moisture content (MC) patch preparations were measured using a moisture analyzer with a temperature of $105^{\circ} \mathrm{C}$ (Kumar et al., 2012). Some patches are placed on an empty aluminum pan that has been cleaned, then the lid is closed and wait until temperature at $105^{\circ} \mathrm{C}$, the measurement of moisture content begins until the tool shows the moisture content of the patch preparation.

\section{RESULTS AND DISCUSSION Celery Herb Extraction}

Dried celery herbs have been pulverized to reduce the size in order to optimize when dissolved into solvent so the extraction process. Amount of 500gram celery herbal powder macerated with ethanol $96 \%$ solvent. The selection of the solvent used is based on the same solubility and polarity (like dissolve like). According to Harborne (1987), flavonoids include polar compounds so they can dissolve and find in $96 \%$ ethanol solvents which are also polar. Ethanol $96 \%$ solvent is the most optimal search fluid with phenolic and flavonoid content parameters (Agustiningsih et al., 2010).

\section{Celery Herb Ethanol Extract}

The yield of celery herb ethanol extract was $5.68 \%$. Organoleptic examination of celery herb ethanol extract showed that the resulting extract was thick in form with a dark green color and a distinctive odor of celery. The results of the water content test of celery herb ethanol extract that is equal to $8.00 \%$ that have fullfil the requirements of the extract water content limit is less than $10 \%$ (MOH RI, 2008).

Identification of flavonoid content in celery herb ethanol extract was carried out qualitatively by thin layer chromatography (TLC). The stationary phase of TLC silica gel is polar, while the mobile phase is n-butanol: acetic acid: water (4: 1: 5) which has higher 


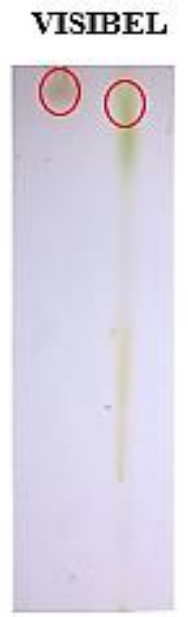

a $\quad \mathbf{b}$

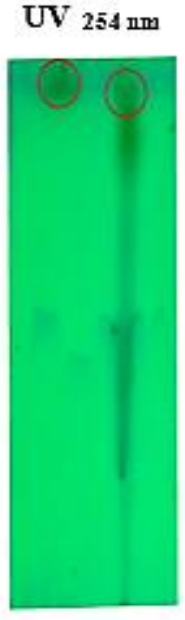

a $\quad \mathbf{b}$

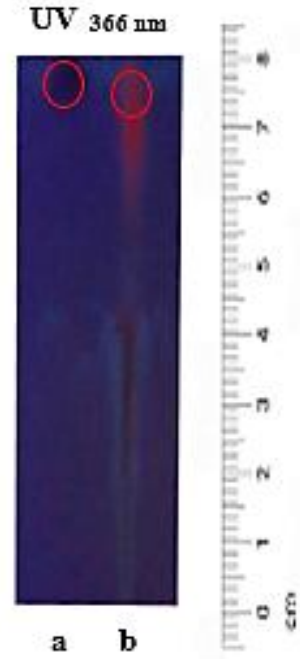

Figure 1. Results of TLC of standard quercetin and celery herb ethanol extract spots were almost parallel with Rf values of 0.96 (a) and 0.94 (b) at UV 254 and UV 366

polarity so that it can separate polar flavonoid compounds. The silica gel TLC plate was roasted to reduce the water content in the TLC plate so that the absorption capacity of the TLC plate was maximum. A chamber filled with a mobile phase (eluent) is saturated first to fill the entire surface of the chamber with eluent vapor so that it can produce good elution (Kusnadi and Devi, 2017).

The standard used in TLC is quercetin because quercetin is a flavonoid total group compound (Azizah et al., 2014). TLC test produced standard quercetin and celery herb ethanol extract spots were almost parallel with $\mathrm{Rf}$ values of 0.96 and 0.94 , respectively. The $\mathrm{Rf}$ value of celery herb ethanol extract is close to the standard Rf value of quercetin. This shows that the ethanol extract of celery herbs contains flavonoid compounds (figure 1).

\section{Result of Physical Properties of Celery Herb Ethanol Extract Patch}

Organoleptic test of patch preparations aims to determine whether there are differences and organoleptic changes in preparations during storage. Organoleptic test results showed the preparation of patch formulas 1,2, and 3 there was no difference, which was typical of the smell of celery and had a patch-shaped appearance with a brownish green color and smooth surface conditions. Organoleptic test at week 0 and week 4 also did not change. This shows that variations in the ratio of polymer concentrations of HPMC and CMC-Na have no effect on organoleptic patch preparations and the resulting patch preparations remain stable during storage at room temperature.

$\mathrm{pH}$ value

The $\mathrm{pH}$ test results in Figure- 3 show that the three formulas before and after storage have met the $\mathrm{pH}$ requirements for preparations that do not irritate the skin, namely 5-9 (Kumar et al., 2012). The $\mathrm{pH}$ value of the three patch formulas decreases during storage, but is still in the $\mathrm{pH}$ range that is safe for the skin so it does not cause skin irritation. Paired samples T-Test results, the $\mathrm{pH}$ of each patch formula during storage obtained sig F1, F2, and F3 respectively 0.017; 0.031 ; and 0.021 , indicating that the $\mathrm{pH}$ of each formula during storage contained a significant difference (sig <0.05). One Way Anova test results between the patch formula obtained sig value 0.114 which indicates that the $\mathrm{pH}$ of the three formulas did not have a significant difference because sig $>0.05$. The results of the analysis showed that the variation in the ratio of polymer concentrations of HPMC and CMC-Na on the ethanol extract of the celery herb extract patch did not significantly influence the $\mathrm{pH}$ value of the preparation.

\section{Thickness Test}

Patch matrix that is thinner will be preferred because it is more comfortable to use and better patch appearance (Setyawan et al., 2014). Graphic Figure-3 shows the thickness of 


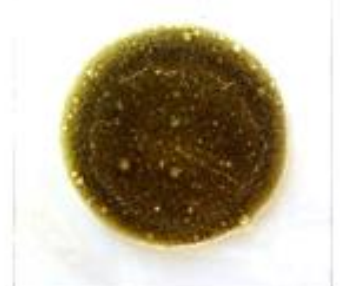

F1

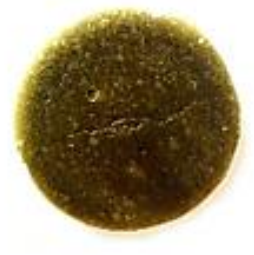

F2

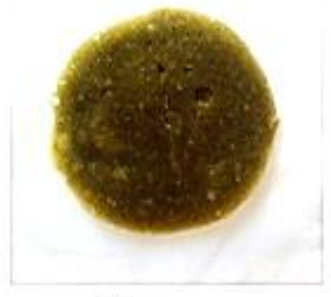

F3

Figure 2. Results of Organoleptics of patch of Celery Herb Ethanolic Extract with polymers combination of HPMC: CMC-Na with ratio of $3: 1$ (F1); 1:1 (F2); and 1:3 (F3)

each patch formula decreases during storage. Formula 3 has the highest thickness value compared to formulas 1 and 2 (F3> F2> F1). The high concentration of $\mathrm{CMC}-\mathrm{Na}$ will produce a thicker patch matrix because CMC-Na is hygroscopic, whereas HPMC polymers will produces a thinner patch matrix (Kurniawati, 2016). Paired Samples T-Test showed that thickness of each patch formula during storage resulted in sig F1, F2, and F3 values respectively are $0.004 ; 0,001$; and 0.006 . The results of the analysis show the thickness of each formula during storage there was a significant difference (sig <0.05). One Way Anova test between patch formulas obtained sig value of 0,000 which indicates the thickness of the three formulas there is a significant difference because sig $<0.05$. Post Hoc test results are known to the group that gives an average difference in thickness value is formula. The analysis results show that the variation of the ratio of HPMC and CMC-Na polymers on the ethanol extract of celery herb patches affects the thickness of the patch, which is increasingly the concentration of CMC-Na polymers compared to HPMC polymers will increase thicker of patch.

\section{Weight Test}

The lighter of patch is more comfortable to use (Kurniawati, 2016). The graph in Figure3 shows the weight of each patch formula decreases during storage. Formula 3 has the greatest weight compared to formulas 1 and 2 (F3> F2> F1). CMC-Napolymer can absorb and retain water in the patch so that the weight of the patch increases. CMC-Na polymer can significantly increase patch weight compared to HPMC polymers (Kurniawati, 2016). Paired Samples Test T-Test for weight of each patch formula during storage resulted in sig values F1, F2, and F3 respectively $0.010 ; 0,000$; and 0.007 .
The results showed the weight of each formula during storage there was a significant difference (sig <0.05). One Way Anova test between formulas obtained sig value of 0.018 . This shows the weight of the three formulas there is a significant difference (sig <0.05). Post Hoc test results are known to the group that gives a difference is formula 1 to formulas 2 and 3 . The analysis results show variations in the ratio of HPMC and CMC-Na polymers in celery herb ethanol extract patche influence the patch weight, where the greater concentration of CMC-Na polymers will increase weight of patch.

\section{Moisture Content Test}

Low moisture content of patches will cause patch brittle, but the high moisture content of the patch will cause patch to be easily overgrown with bacteria (Mukherjee et al, 2005). The graph in Figure-3 shows the humidity value of each patch formula decreases during storage. Formula 3 has the highest moisture content compared to formulas 1 and 2 (F3> F2> F1). CMC-Na polymers have hygroscopic properties so that they can absorb and retain water (Rowe et al., 2009). HPMC polymers can increase the permeability of the patch matrix so that water will more easily come out of the preparation during drying (Kurniawati, 2016). Propylenglycol also plays a role in increasing patch humidity because it is hygroscopic (Rowe et al., 2009). The moisture value of patch preparations on the market with the brand "Kool Fever" is $52.46 \%$. The moisture content of the formula 1 week 0 approaches the "Kool Fever" patch, but the 4th week is significantly different. The moisture content of formula 2 at weeks 0 and 4 approaches the "Kool Fever" patch. The moisture content of the formula 3 weeks to 0 and 4 is higher than the 

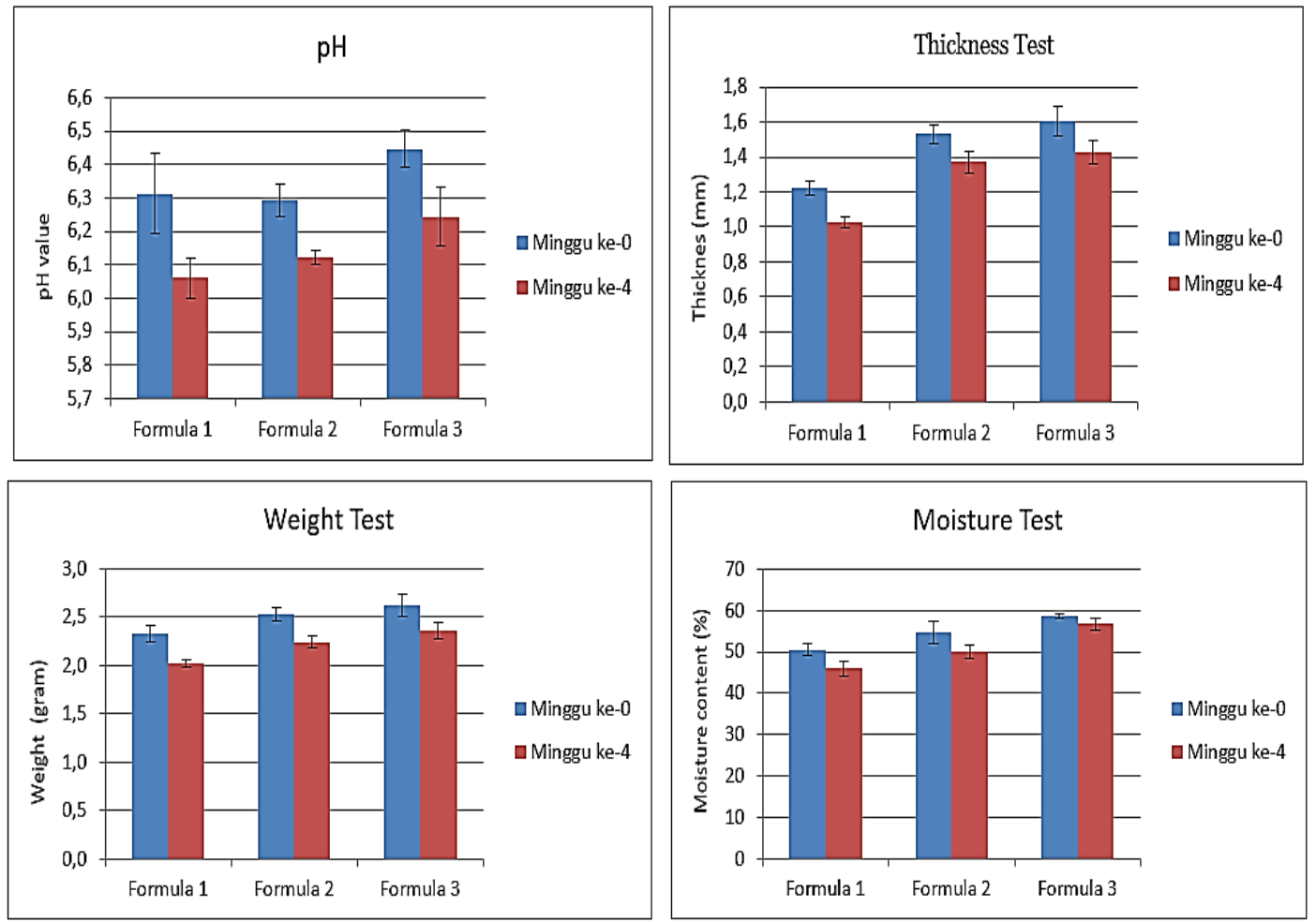

Figure 3. Results of $\mathrm{pH}$ value, Thickness, Weight and Moisture content of each patch formula during storage for 4 weeks obtained F1, F2, and F3 have significant difference ( $\operatorname{sig}<0.05$ ). Results show that the variation of the ratio of HPMC and CMC-Na polymers on the ethanol extract of celery herb patches affects to the physical caracteristics, which is increasingly the concentration of CMCNa polymers compared to HPMC polymers.

Table II. Results of folding endurance test of celery herb sthanolis extract patch during 4 weeks

\begin{tabular}{cccc}
\hline Formula & \multirow{2}{*}{ Replication } & \multicolumn{2}{c}{ Weeks } \\
\cline { 3 - 4 } [HPMC : CMC-Na] & & 0 & $\mathbf{4}$ \\
\hline \multirow{2}{*}{ F1 $[3: 1]$} & I & $>300$ & $>300$ \\
& II & $>300$ & $>300$ \\
& III & $>300$ & $>300$ \\
F2 [1:1] & I & $>300$ & $>300$ \\
& II & $>300$ & $>300$ \\
& III & $>300$ & $>300$ \\
F3 [1:3] & I & $>300$ & $>300$ \\
& II & $>300$ & $>300$ \\
\hline
\end{tabular}

"Kool Fever" patch and the difference is quite significant.

Paired Samples T-Test Moisture test of each formula during storage resulted in sig F1, F2, and F3 values respectively $0.043 ; 0.094$; and 0.060 . These results indicate the humidity of formula 1 during storage there is a significant difference (sig <0.05). Moisture formula 2 and 3 during storage there is no significant difference (sig>0.05). One Way Anova test results obtained between the formula sig value of 0.000 , which means the humidity patch of the three formulas is significantly different ( $\mathrm{sig}<0.05)$. The Post Hoc Test found that formulas 1, 2, and 3 each gave significant differences. The results of the analysis showed variations in the polymer 
concentration of HPMC and CMC-Na on the ethanol extract of the celery herb extract patch affected the moisture patch, where the greater the concentration of the CMC-Na polymer compared to HPMC, the higher the moisture patch produced.

Folding Endurence of Patch

The greater of folding endurance of patch means that met good quality patch, because the patch is not easily damaged or broken. The results that showed at table, it is means that number of folds of the three formulas are $>300$ times. This shows that the three patch formulas have met the requirements of good folding endurance $>300$ folds (Jhawat et al., 2013). Variation concentration of HPMC polymer and CMC-Na in each formula did not affect the folding endurance of celery herb ethanol extract patches. The folding endurance of patch is caused by the influence of the use of plasticizer of PEG 400 so that it can produce a flexible patch that are not easily damaged or broken.

\section{CONCLUTIONS}

Sodium Carboxylmethylcellulose affected to physical properties of patch of celery herb (Apium graveolens L.) ethanolic extract, include: thickness, weight, and moisture. Formula 2 with combination of HPMC : CMC-Na (1:1) was the best formula because it meets the requirements of good physical properties of patch there were : $\mathrm{pH}$ value of 6.12-6.29; thickness 1.37 -1.53 mm; weighing 2.24-2.52 grams; folding endurance > 300 times, and moist patch compare with brand product.

\section{DAFTAR PUSTAKA}

Agustiningsih, Wildan, A., dan Mindaningsih, 2010, Optimasi Cairan Penyari pada Pembuatan Ekstrak Daun Pandan Wangi (Pandanus amaryllifous Roxb secara Maserasi Terhadap Kadar Fenolik dan Flavonoid Total, Momentum, 6(2): 36-41.

Al-Snafi, A.E., 2014, The Pharmacology of Apium graveolens - A Review, International Journal for Pharmaceutical Research Scholars, 3(1-1): 671-677.

Azizah, D. N., Kumolowati, E., dan Faramayuda, F., 2014, Penetapan Kadar Flavonoid Metode $\mathrm{AlCl}_{3}$ pada Ekstrak Metanol Kulit Buah Kakao (Theobroma cacao L.), Kartika Jurnal Ilmiah Farmasi, 2(2): 4549.
Depkes RI, 2008, Farmakope Herbal Indonesia, Departemen Kesehatan Republik Indonesia, Jakarta.

Dewi, K., Jasaputra, D.K., dan Litanto, O., 2010, Efek Ekstrak Etanol Seledri (Apium graveolens L.) Terhadap Tekanan Darah Pria Dewasa,Jurnal Medika Planta,1(2).

Harborne, J.B., 1987, Metode Fitokimia Edisi ke2, diterjemahkan oleh Padmawinata, K. dan Soediro, I., Penerbit ITB, Bandung, Terjemahan dari: Phytochemical Methods.

Jhawat, Saini, Kamboj, dan Maggon, 2013, Transdermal Drug Delivery System: Approaches and Advancements in Drugs Absorbtion Through Skin, Int. J. Pharm Sci Rev, 20(1): 47-56.

Kumar, S.R., Ashish, J., dan Satish, N., 2012, Development and Evaluation of Transdermal Patches of Colchicine. Der Pharmacia Lettre, 4(1): 330-343.

Kurniawati, E., 2016, Formulasi Matriks Patch Ekstrak Bunga Rosela (Hibiscus sabdariffa L.) dan Aktivitasnya terhadap Sel Pre Adiposa 3T3-L1, Tesis, Fakultas Farmasi, Universitas Gadjah Mada, Yogyakarta.

Kusnadi, K. dan Devi, E.T., 2017, Isolasi dan Identifikasi Senyawa Flavonoid pada Ekstrak Daun Seledri (Apium graveolens L.) dengan Metode Refluks, Pancasakti Science Education Journal, 2(1): 56-67.

Madhulata, A. dan Naga, R.K.T, 2013, Formulation and Evaluation of Ibuprofen Transdermal Patches, International Journal of Research in Pharmaceutical and Biomedical Science, 4(1): 351-361.

Mukherjee, B., Kanupriya, M.S., Das, S., dan Patra, B., 2005, Sorbitan Monolaurate 20 as a Potential Skin Permeation Enhancer in Transdermal Patches, J Appl Res, 1: 96108.

Palmer, A.W., 2007, Tekanan Darah Tinggi, Erlangga, Jakarta.

Parivesh, S., Sumeet, D., dan Abhishek, D., 2010, Design, Evaluation, Parameters and Marketed Products of Transdermal Patches: A Review.Journal of Pharmacy Research,3.

Patel, D., Chaudhary, S.A., Bavesh, P., dan Nikunj, P., 2012, Transdermal Drug Delivery System, The Pharma Innovation, 1(4): 7787.

Prabhu, P., Shah, S., dan Gundad, S., 2011, Formulation development and 
Investigation of Domperidone Transdermal Patches, International Journal of Pharmaceutical Investigation, 1: $240-246$.

Puspitasari, K. D., Nurahmanto, D., dan Ameliana, L., 2016, Optimasi Hidroksipropil Metilselulosa dan Carbopol terhadap Moisture Content dan Laju Pelepasan Patch Ibuprofen In Vitro, e-Jurnal Pustaka Kesehatan, 4(2): 229234.

Rowe, R.C., Sheskey, P.J., dan Quinn, M.E., 2009, Handbook of Pharmaceutical Excipients, Pharmaceutical Press, London.

Sa'adah, H. dan Nurhasnawati, H., 2015, Perbandingan Pelarut Etanol dan Air pada Pembuatan Ekstrak Umbi Bawang Tiwai (Eleutherine americana Merr) Menggunakan Metode Maserasi, Jurnal Ilmiah Manuntung, 1(2): 149-153).

Saputra, O. dan Fitria, T., 2016, Khasiat Daun Seledri (Apium graveolens) Terhadap Tekanan Darah Tinggi Pada Pasien
Hiperkolestrolemia, Majority, 5(2):120125.

Setyawan, E.I., Pratama, P.Y.A., dan Budiputra, D.K., 2014, Optimasi Formula Matriks Patch Ketoprofen Transdermal Menggunakan Kombinasi Asam Oleat dan Minyak Atsiri Bunga Cempaka Putih (Michelia alba) sebagai Permeation Enhancer. Fakultas Farmasi FMIPA. Universitas Udayana, Bali.

Sharma, K., Singh, V., \& Arora, A., 2011, Natural Biodegradable Polymers as Matrices in Transdermal Drug Delivery, International Journal of Drug Development \& Research, 3(2): 85-103.

Valenta, C. dan Auner, B.G., 2004, The Use of Polymers for Dermal and Transdermal Delivery. European Journal of Pharmaceutics and Biopharmaceutics, 58: 279-289.

Williams, A.C. dan Barry, B.W., 2004, Penetration Enhancer, Advanced Drug Delivery Reviews, 56: 603-618. 